\title{
Providing Care with Cultural, Racial, and Ethnic Humility: the Framework for an Additional Entrustable Professional Activity
}

\author{
Irfan A. Khan ${ }^{1}$ (D ) Nicholas B. Conway ${ }^{1} \cdot$ Maryam Ali $^{1} \cdot$ Christina Rios $^{1,2} \cdot$ Cheryl L. Holder $^{1} \cdot$ Vivian T. Obeso $^{1}$
}

Accepted: 21 January 2022 / Published online: 1 February 2022

(c) The Author(s) under exclusive licence to International Association of Medical Science Educators 2022

\begin{abstract}
Healthcare inequities are rampant in the USA. There is a lack of standardization for training medical students in providing care with cultural, racial, and ethnic humility. This innovation is the framework of an entrustable professional activity that can be utilized to address this vital issue.
\end{abstract}

Keywords Entrustable professional activity · Physician competencies · Undergraduate medical education · Social accountability $\cdot$ Health inequities

\section{Innovation}

Social justice is a pillar of bioethics that has been taught in medical school since the inception of medical education. [1] Flash forward to today, Black mothers are 3.4 times more likely to die while delivering their child when compared to White mothers, [2] and COVID-19 hospitalization rates are 5 times and 4 times higher for non-Hispanic Black Americans and Hispanics/Latinos, respectively, when compared to non-Hispanic White Americans. [3] It is grossly apparent that social injustice and inequities are rampant throughout healthcare in the United States of America. This has only been magnified during the COVID-19 pandemic and highlighted with the recent social justice movements. One of the numerous contributing factors is the lack of standardization within medical education when it comes to training medical students in providing care with cultural, racial, and ethnic humility. Addressing and rebuilding the system will take a conscious effort from individuals in all stages of their careers, from clinical and academic faculty members to medical students.

Recently, there was a call for medical professionals to gain "competency" in addressing and managing patients from various backgrounds. [4] Using the entrustable

Irfan A. Khan

ikhan018@med.fiu.edu

1 Herbert Wertheim College of Medicine, Florida International University, Miami, USA

2 Department of Psychiatry, College of Medicine, University of Kentucky, Lexington, USA professional activity (EPA) framework and the one-page schematic model used in the Core EPA toolkits, $[5,6]$ we are proposing a new EPA aimed to prepare medical students to provide competent care on the first day of their graduate medical training regardless of a patient's culture, race, or ethnicity (Fig. 1). The framework includes four key functions, which translate relevant components of five of the eight Association of American Medical Colleges (AAMC) Physician Competency Reference Set (PCRS) competencies (patient care [PC], knowledge for practice [KP], practicebased learning and improvement [PBLI], professionalism $[\mathrm{P}]$, and personal and professional development [PPD]) into actionable, observable behaviors that can be used for training and assessment of this EPA in the pre-clinical and clinical settings. [7] These four key functions are demonstrating an awareness of implicit bias, identifying various presentations for conditions in patients of color, critical analysis of race-dependent clinical algorithms, and using patient-centered communication to learn about a patient's beliefs and incorporating them when developing treatment plans. For each function, we described developing behaviors that culminate in the expected entrustable behavior for this new EPA.

It is essential that diversity, equity, and inclusion (DEI) competencies be addressed nationally among all medical schools in the USA to ameliorate the health inequities facing underrepresented and minority communities. Physicians who can recognize their own intrinsic bias can work to mitigate that influence in the treatment of patients. Being able to recognize different manifestations of conditions 


\begin{tabular}{|c|c|c|c|c|}
\hline $\begin{array}{l}\text { Key Functions with Related } \\
\text { Physician Competencies }\end{array}$ & $\begin{array}{l}\text { Behaviors Requiring } \\
\text { Corrective Response }\end{array}$ & $\stackrel{\text { Developing } B}{\text { (Learner may be at different I }}$ & $\begin{array}{l}\text { viors } \quad \rightarrow \\
\text { s within each section) }\end{array}$ & $\begin{array}{l}\text { Expected Behavior for } \\
\text { an Entrustable Learner }\end{array}$ \\
\hline $\begin{array}{l}\text { Become aware of } \\
\text { personal attitudes } \\
\text { regarding healthcare } \\
\text { delivery and any } \\
\text { underlying cultural, } \\
\text { racial, or implicit } \\
\text { biases } \\
\text { PBLI 3.1, PBLI 3.3, PPD } \\
\text { 8.3, SA 9.4 }\end{array}$ & $\begin{array}{l}\text { Not willing } \\
\text { to evaluate } \\
\text { and become } \\
\text { aware of } \\
\text { personal } \\
\text { beliefs and } \\
\text { biases; may } \\
\text { become } \\
\text { defensive }\end{array}$ & $\begin{array}{l}\text { Does not display a recognition } \\
\text { of personal biases. } \\
\text { Uncomfortable while } \\
\text { participating in discussions } \\
\text { regarding bias. } \\
\text { Completes course work and/or } \\
\text { assessments related to bias. }\end{array}$ & $\begin{array}{l}\text { Reflects on experiences } \\
\text { where personal bias or the } \\
\text { bias of others may have led } \\
\text { to delivering sub-optimal } \\
\text { care. } \\
\text { Actively participates in } \\
\text { lectures and discussions } \\
\text { regarding bias. }\end{array}$ & $\begin{array}{l}\text { Display in-depth } \\
\text { knowledge about } \\
\text { personal beliefs and } \\
\text { biases, and how they } \\
\text { may influence the } \\
\text { delivery of patient care. }\end{array}$ \\
\hline $\begin{array}{l}\text { Recognize variation in } \\
\text { symptoms and } \\
\text { different } \\
\text { manifestations of } \\
\text { conditions prevalent } \\
\text { in different groups of } \\
\text { individuals. } \\
\text { PC 1.2, KP 2.2, KP 2.4, } \\
\text { PBLI 3.9 }\end{array}$ & $\begin{array}{l}\text { Unaware that } \\
\text { symptoms or } \\
\text { manifestations } \\
\text { of diseases } \\
\text { may differ } \\
\text { amongst } \\
\text { patients from } \\
\text { various } \\
\text { backgrounds. }\end{array}$ & $\begin{array}{l}\text { Fails to recognize variations } \\
\text { of disease processes, such as } \\
\text { skin lesions on dark-skinned } \\
\text { individuals. } \\
\text { May generalize based on age, } \\
\text { gender, culture, race, } \\
\text { religion, disabilities, and/or } \\
\text { sexual orientation. }\end{array}$ & $\begin{array}{l}\text { Considers cultural and other } \\
\text { factors that may influence } \\
\text { the patient's description of } \\
\text { symptoms or health history, } \\
\text { Accounts for patient } \\
\text { preferences during exam, } \\
\text { including gender of the } \\
\text { healthcare professional. }\end{array}$ & $\begin{array}{l}\text { Accurately and timely } \\
\text { identifies varying } \\
\text { presentations of } \\
\text { diseases in different } \\
\text { groups of patients } \\
\text { through a complete } \\
\text { history and physical } \\
\text { examination. }\end{array}$ \\
\hline $\begin{array}{l}\text { Critically analyze } \\
\text { race-adjusted } \\
\text { algorithms to guide } \\
\text { appropriate } \\
\text { management and } \\
\text { prevent worsening of } \\
\text { health inequities. } \\
\text { PC 1.3, PC 1.5, PC 1.6, } \\
\text { PBLI 3.8, PBLI 3.10 }\end{array}$ & $\begin{array}{l}\text { Denies that } \\
\text { race being } \\
\text { included in } \\
\text { clinical } \\
\text { algorithms } \\
\text { may } \\
\text { exacerbate } \\
\text { health } \\
\text { inequities. }\end{array}$ & $\begin{array}{l}\text { Unsure of situations during } \\
\text { which race-based diagnostic } \\
\text { tools may be utilized. } \\
\text { Is not aware of how race or } \\
\text { ethnicity-based adjustments } \\
\text { for diagnostic algorithms can } \\
\text { worsen health inequalities. }\end{array}$ & $\begin{array}{l}\text { Aware of how race- } \\
\text { adjusted algorithms can } \\
\text { worsen health inequities. } \\
\text { Can provide examples of } \\
\text { race-adjusted algorithms } \\
\text { with potential to worsen } \\
\text { health inequities. }\end{array}$ & $\begin{array}{l}\text { Critically analyzes race } \\
\text { incorporation into } \\
\text { diagnostic algorithms to } \\
\text { prevent worsening of } \\
\text { health inequities. }\end{array}$ \\
\hline $\begin{array}{l}\text { Develop treatment } \\
\text { plans based on the } \\
\text { patient's values and } \\
\text { beliefs, which } \\
\text { influence health, care } \\
\text { adherence, barriers } \\
\text { to care, and attitudes } \\
\text { toward care. } \\
\text { PC 1.6, PC 1.7, KP 2.5, } \\
\text { PBLI 3.9, P 5.2 }\end{array}$ & $\begin{array}{l}\text { Does not } \\
\text { believe that } \\
\text { patient } \\
\text { factors such } \\
\text { as beliefs, } \\
\text { personal } \\
\text { values can } \\
\text { influence } \\
\text { outcomes, } \\
\text { dismissive }\end{array}$ & $\begin{array}{l}\text { Describes plan without } \\
\text { considering patient values, } \\
\text { beliefs or preferences. }\end{array}$ & $\begin{array}{l}\text { Recognizes the role an } \\
\text { individual's beliefs and } \\
\text { values play in their } \\
\text { medical decision making } \\
\text { and prioritizes those. } \\
\text { Includes individuals in the } \\
\text { medical planning process } \\
\text { whose participation the } \\
\text { patient would like. }\end{array}$ & $\begin{array}{l}\text { Partners with patients } \\
\text { and their care units to } \\
\text { create a treatment plan } \\
\text { consistent with their } \\
\text { personal values and } \\
\text { beliefs. }\end{array}$ \\
\hline
\end{tabular}

Fig. 1 Providing care with cultural, racial, and ethnic humility—one-page schematic with developmental behaviors

such as dermatological lesions in patients of color can help to prevent delays in diagnosis (or misdiagnosis) and will improve health outcomes. Critically analyzing the role of race-adjusted clinical algorithms can help prevent worsening of health inequities. [8] Lastly, being able to effectively communicate with patients and develop treatment plans in accordance with their own beliefs will not only help to improve healthcare outcomes and adherence but also help mend the distrust that is prevalent in many communities toward healthcare.

By the time students graduate from medical school, they should be entrustable in this new EPA. This one-page schematic can serve as a road map for students and faculty. Understanding how these concepts can and should be applied clinically on a regular basis is the first step toward the development of a more robust training and assessment system. Given the enthusiasm by faculty members and students for the new EPA, it is being piloted at the Florida International University Herbert Wertheim College of Medicine (FIU HWCOM). As a first step in the implementation process, we have identified opportunities for integration of the EPA across the curriculum. For example, it can be incorporated through implementing an implicit bias assessment with opportunity for reflection, integrating key patient care components into the pre-clerkship clinical skills course, and developing a patientbased assignment that involves the critical analysis of a raceadjusted diagnostic tool within the Internal Medicine Clerkship. Next steps will include the development of a workplace-based assessment tool using this one-page schematic along with concomitant faculty development and student engagement. 
Identifying opportunities to incorporate meaningful change in medical education and providing students with clear expectations, a roadmap, and proactive goals regarding their delivery of care to patients is expected to result in small steps toward systematic change, with medical students and faculty members being more confident in their ability to provide care to all patients with cultural, racial, and ethnic humility. We believe this framework will help train the next generation of socially accountable physicians who are aware of their own intrinsic bias and who can provide care with humility and respect for all regardless of race, ethnicity, or creed. The time for change is now; as we are piloting this at our own institution, we encourage others to do the same.

\section{Declarations}

Ethics Approval Not applicable.

Consent to Participate Not applicable.

Consent for Publication Not applicable.

Competing Interests The authors declare no competing interests.

\section{References}

1. Kirch DG. Academic medicine and social justice. AAMC. https:// www.aamc.org/news-insights/insights/academic-medicine-andsocial-justice. Published September 27, 2016.
2. Creanga AA, Syverson C, Seed K, Callaghan WM. Pregnancyrelated mortality in the United States, 2011-2013. Obstet Gynecol. 2017;130(2):366-73.

3. Centers for Disease Control and Prevention. COVID-19 in racial and ethnic minority groups. Atlanta, GA: CDC, U.S. Dept Health and Hum Servi. 2020.

4. Hardeman RR, Medina EM, Boyd RW. Stolen breaths. N Engl J Med. 2020;383(3):197-9. https://doi.org/10.1056/nejmp2021072.

5. Core entrustable professional activities for entering residency curriculum developers' guide. Assoc Am Med Coll. https://store. aamc.org/downloadable/download/sample/sample_id/63/\%20.

6. Obeso V, Brown D, Aiyer M, Barron B, Bull J, Carter T, Emery M, Gillespie C, Hormann M, Hyderi A, Lupi C. Toolkits for the 13 core entrustable professional activities for entering residency. Washington, DC: Assoc Am Med Coll. 2017.

7. CI Physician Competency Reference Set (PCRS). AAMC. https:// www.aamc.org/what-we-do/mission-areas/medical-education/ curriculum-inventory/establish-your-ci/physician-competencyreference-set.

8. Vyas DA, Eisenstein LG, Jones DS. Hidden in plain sight reconsidering the use of race correction in clinical algorithms. N Engl J Med. 2020;383(9):874-82. https://doi.org/10.1056/ NEJMms2004740.

Publisher's Note Springer Nature remains neutral with regard to jurisdictional claims in published maps and institutional affiliations. 